\title{
Hemodiyaliz hastalarında gizli Hepatit B enfeksiyonunun polimeraz zincir reaksiyonu ile araştıııması
}

\section{Polymerase chain reaction with investigation of occult Hepatitis B infection in hemodialysis patients}

Ünsal SAVCl ${ }^{\mathrm{a}}$, Yunus BULUT

Gaziosmanpaşa Üniversitesi Tıp Fakültesi, Mikrobiyoloji ve Klinik Mikrobiyoloji Anabilim Dalı, Tokat-TÜRKIYE

\begin{abstract}
ÖZET
Amaç: Serumda Hepatit B virüsü yüzey antijeninin (HBsAg) negatif olduğu durumlarda, Hepatit B virüs DNA'sının (HBV DNA) düşük titrede varlı̆ı gizli Hepatit B olarak bilinmektedir. Uzun dönem hemodiyaliz uygulanan hastalarda gizli Hepatit B enfeksiyon prevalansı ile ilgili çalışmalar sınırıdır. HBsAg testi negatifleşen bazı hastaların plazma ve karaciğer dokusunda HBV varlığı devam edebilmektedir. Bu durum tanısal sorunlara neden olmaktadır. Bu klinik tabloya sahip kişilerin HBV bulaştırıcılı̆ı̆ yönünden toplumda, özellikle diyaliz ünitelerinde potansiyel bulaş riski oluşturmaları nedeniyle tespit edilmeleri çok önemlidir. Bu çalışmada diyaliz hastalarda gizli Hepatit B prevelansının belirlenmesi amaçlanmışır.

Yöntem ve Gereçler: Bu çalışmada hemodiyaliz uygulanan, HBsAg negatif 160 hasta ve 28 prediyaliz hastası olmak üzere toplam 188 hasta çalışmaya dahil edildi. Hastalardan 5'er ml venöz kan örneği antikoagülan içermeyen steril vacutainer tüplerine alındı. Serumu ayrıştırmak için kanın alındığı tüp 800-1600 x g'de 20 dakika santrifüjlendi. Ayrıştıılan serum polipropilen tüplere alındı ve -20 $C^{\circ}$ de test prosedürü uygulanana kadar saklandı.

HBV DNA'nın saptanmasında; HBV İzolasyon Cihazı ( Magnesia 16 Anatolia Geneworks, Türkiye) ve HBV DNA izolasyon kiti (16 / 201 Viral Nükleik asit izolasyon kiti) kullanıılı ve izole edilen serumlar elüsyon tüpüne alınarak etiketlendi. PCR sürecinde Real-Time PCR Cihazı (Montania 483 Anatolia Geneworks, Türkiye) ve Real-time PCR kiti (Bosphore Quantification Kit V2) kullanıldı. Kullanılan Real-time PCR kiti, insan serum veya plazma örneklerindeki Hepatit B Virüsü DNA'sının A-H arasındaki tüm HBV genotiplerini saptamakta ve miktarını belirlemekteydi. Kitin analitik duyarlıı̆ı $10 \mathrm{lU} / \mathrm{ml}$, lineer aralığı 1×101-1×109 IU/ml idi.

Hepatit B virus belirteçleri (HBsAg, anti-HBCAg, anti-HBs) ticari ELISA kitleri (Abbott ARCHITECT Qualitative Reagen Kit) ve ELISA cihazI (Abbott ARCHITECT i2000 SR), CRP (SIEMENS CardioPhase hsCRP) kiti ve SIEMENS BN II cihazı kullanılarak çalışldı. Aynı şekilde, aspartat aminotransferaz (AST) , alanin aminotransferaz (ALT), (Aspartate aminotransferase / Alanine aminotransferase Roche Cobas INTEGRA/cobas C system ) test kitleri kullanılarak Roche Cobas 501 cihazı ile çalışıld.
\end{abstract}

Bulgular: Hemodiyaliz hastalarının \%11,3'ünde (18/160) izole HBV DNA pozitifliği (gizli Hepatit B enfeksiyonu) saptandı. Kontrol grubu olarak prediyaliz hastalarında ise HBV DNA pozitifliğine rastlanmadı (0/28). Anti-HBs pozitifliği hemodiyaliz hastalarını 142 'sinde $(\% 88,7)$, prediyaliz hastalarının ise 14 'ünde $(\% 50)$ saptandı $(p<0,05)$. Diğer parametreler arasında istatistiksel olarak anlamlı bir fark yoktu.

Sonuç: Diyaliz merkezleri HBV bulaşı açııından riskli alanlardir. Diyaliz uygulanan tüm hastaların HVB DNA taramaları yapılmalıdr. Ayrıca duyarlı hastaların aşlanmaSı, GHB tanısı konulmuş hastaların diyalizörlerinin izole edilmesi, HBV tanıS alan hastaların spesifik bir servise alınması da önerilebilir.

Anahtar Kelimeler: HBV, gizli Hepatit B, hemodiyaliz

Sorumlu Yazara: Uz. Mikrobiyolog Ünsal SAVCI

Gaziosmanpaşa Üniversitesi Tıp Fakültesi, Mikrobiyoloji ve Klinik Mikrobiyoloji Anabilim Dalı, Tokat.

E-mail: unsalsavci@gmail.com

Gsm: +90 5056431925

Submitted: 24.02.2015 Accepted: 26.03.2015 


\section{ABSTRACT}

Aim: It is known as the occult Hepatitis B that Hepatitis B virüs DNA (HBV DNA) exists in serum very little if Hepatitis B virus surface antigen in serum is negative. The studies about occult Hepatitis $B$ infection prevalence are limited in patients who undergo hemodialysis implements for along time. HBV existence is able to continue in plasma and liver tissue of some patients whose HBsAg test is negative. This condition causes many diagnostic problems. It is very crucial the description of people who have this clinical risk of HBV transmission in the community, especially in dialysis units. This study is aimed to determine the prevalence of occult Hepatitis B in dialysis patients.

Material and Methods:160 HBsAg-negative patients and 28 predialysis total of 188 patients were included in this study. $5 \mathrm{ml}$ venous blood samples taken from the patients into sterile vacutainer tubes contain anticoagulant. Blood tubes to separate serum 800-1600 x g for $20 \mathrm{~min}$. centrifuged. The separated serum was collected into polypropylene tubes and was stored at $-20^{\circ} \mathrm{C}$ until the applied test procedure.

For the detection of HBV DNA; HBV Isolation Device (Magnesia 16 Geneworks Anatolia, Turkey) and HBV DNA isolation kit (16/201 viral nucleic acid isolation kit) was used and isolated, then serum were tagged on the elution tube. Real-Time PCR Device (Montanide 483 Geneworks Anatolia, Turkey) and Real-time PCR kit (Bosphore Quantification Kit V2) was used in PCR process. Real Time PCR kit, which is used in the study, was detected whole HBV genotypes between $\mathrm{A}$ and $\mathrm{H}$ of the Hepatit $\mathrm{B}$ virus DNA in human serum or plasma sample. Analytical sensitivity of the kit was $10 \mathrm{lU} / \mathrm{mL}$ linear range 1×101-1×109 IU/ml.

Hepatitis B virus markers (HBsAg, anti-HBcAg, anti-HBs) ) were studied using commercial ELISA kits (Abbott ARCHITECT Qualitative Reagan Kit) and ELISA device (Abbott ARCHITECT i2000 SR), CRP (SIEMENS cardiophase to hSCRP the kit and SIEMENS BN II device. Likewise, aspartate aminotransferase (AST), alanine aminotransferase (ALT), (aspartate aminotransferase A / Alanine aminotransferase Roche Cobas INTEGRA / cobas c system) were studied using with test kits Roche Cobas 501 devices.

Results: In 11.3\% of hemodialysis patients (18/160) HBV DNA positivity (occult Hepatitis B infection) were detected. Predialysis patients who are in the control group was not observed HBV DNA positivity (0/28). Anti-HBs positivity in 142 hemodialysis patients (88.7\%), while 14 predialysis patients $(50 \%)$ were found $(\mathrm{p}<0.05)$. There was no statistically significant difference between the other parameters.

Conclusions:Dialysis centers are areas of risk for transmission of HBV. HBV DNA screening of all patients undergoing dialysis must be performed In addition; suggested to vaccination of susceptible patients, GHB has been diagnosed patients isolating dialyzer, the diagnosis of HBV patients receiving a specific service area.

Key Words: HBV, occult Hepatitis B, hemodialysis

\section{Giriş}

HBV enfeksiyonu; global bir halk sağlı̆ı problemidir ve dünyada en sık görülen bulaşıcı hastallklardan birisidir. WHO; dünya popülasyonunun 1/3'ünden daha fazlasının HBV ile enfekte olduğunu tahmin etmektedir [1].

HBV enfeksiyonunun tanısında serolojik göstergeler bazı durumlarda yetersiz kalabilir. Gizli HBV enfeksiyonunda viral replikasyonun gösterilmesi için HBV DNA araştııımalııır [2].

Gizli HBV enfeksiyonunun tanıss için, duyarllığı yüksek HBV DNA polimeraz zincir reaksiyonu (PCR) testi gerekir. PCR testleri kullanılarak 10 kopya/ml DNA dahi, çoğaltılarak tespit edilebilir [2,3].

Uzun dönem hemodiyaliz uygulanan hastalarında gizli Hepatit B enfeksiyonu prevalansılyla ilgili çalışmalar sınırlıdır. Yapılan bu çalışmalarda hemodiyaliz hastalarında gizli Hepatit B enfeksiyon oranı \% 0-58 arasindadır [4].

Gizli Hepatit B enfeksiyonunun bulaşıp bulaşmayacağl; diğer viral enfeksiyonlarda olduğu gibi HBV enfeksiyonunun seyri de alınan viral yüke ve hastanın immün durumuyla yakından ilişkilidir. Genel olarak benimsenen görüş; alınan kanda HBV DNA varsa enfeksiyon oluşabilir şeklindedir [5].

HBsAg negatif, PCR yöntemiyle HBV DNA pozitif olan hastaların serumları şempanzelere verilmesi sonucu akut hepatit geliştiği görülmüş, hem insanlarda hem de şempanzelerde akut hepatit gelişmesinden sonra alınan DNA örnekleri karşılaştırıldığında insana ve şempanzeye ait DNA' larının aynı olduğu görülmüştür [6].

Hemodiyaliz hastalarında; bozulmuş konak immün yanıtı ve çoklu transfüzyon gereksinimlerinden dolayı parenteral olarak viral ajanların bulaşması ile potansiyel olarak enfeksiyon riski artmıştır. Viral hepatitler hemodiyaliz hastalarında önemli bir problem olarak kabul edilir. Çünkü bu popülasyonda görülen ölümlerin $\% 1,9^{\prime} u$ viral hepatitlerin sonucudur [7].

Hepatit B virüsü hemodiyaliz hastalarında parenteral yol ile bulaşan enfeksiyonların en önemli nedenlerinden birisidir [7].

Zamanımızdan yaklaşık 35 yı öncesinde HBV enfeksiyonu diyaliz ünitelerinde çok yaygındı ve çok ciddi bir tehdit olarak algılanıyordu. Bahsedilen bazı diyaliz ünitelerinde HBsAg prevalansı o zamanlarda \% 50'nin üzerine çıkmışı. Amerika Birleşik Devletleri "Hastalıkları Kontrol Merkezi (CDC)" nin uygulamaları olan; HBsAg pozitif hastaların HBsAg negatif olan hastalardan farklı diyaliz cihazlarına alınması, diyaliz ekipmanlarının ve personelin özel olması ve hijyen kurallarına dikkat edilmesi sonucunda hemodiyaliz ünitelerinde HBsAg prevalansında hızı bir düşüş yaşanmışıtı [8].

PCR metotlarının sensitivite ve spesifitelerinin geliştirilmesi ile HBV DNA taşıyan bireylerin HBV DNA için $10 \mathrm{IU} / \mathrm{ml}$ limitlerinden daha azını tespit edilebilmesini sağlamışıı [9]. 
Bu çalışmada hemodiyaliz hastalarında, polimeraz zincir reaksiyonu (PCR) ile gizli Hepatit B prevelansının belirlenmesi amaçlanmıştır.

\section{Gereç ve Yöntemler}

Çalışmaya hemodiyaliz uygulanan HBsAg negatif toplam 160 hasta ve kontrol grubu olarak kronik böbrek yetmezliği olan, fakat hemodiyaliz uygulanmayan HBsAg negatif 28 hasta olmak üzere toplam 188 hasta dahil edildi. Hastalardan 5'er $\mathrm{ml}$ venöz kan örnekleri antikoagülan içermeyen steril üç farklı tüpe alındı. Alınan kan örnekleri, serumu ayrıştırmak için kanın alındığı tüp 800-1600 g'de 20 dakika santrifüjlendi. Hepatit belirteçleri ticari ELISA kitleri (Abbott ARCHITECT Qualitative Reagen Kit) ve ELISA cihazI (Abbott ARCHITECT i2000 SR), CRP kiti (SIEMENS CardioPhase hsCRP) ve SIEMENS BN II cihazı, AST (aspartat aminotransferaz), ALT (alanin aminotransferaz), (Aspartate aminotransferasee/Alanine aminotransferasee Roche Cobas INTEGRA/ cobas c system ) test kit ve Roche Cobas 501 cihazı kullanılarak çalışıldı. Kalan serumlar polipropilen tüplere alındı ve $-20^{\circ} \mathrm{C}$ 'de DNA izolasyonu ve PCR çalışmaları için saklandı.

DNA izolasyonu; HBV İzolasyon Cihazı ( Magnesia 16 Anatolia Geneworks, Türkiye) ve HBV DNA izolasyon kiti (16/201 Viral Nükleik asit izolasyon kiti) ile üretici firmanın talimatları uyarınca yapıldı. İzolasyon cihazı çalıştırıldı ve 56 dakika sonra işlem sona erdi. İzole edilen serumlar elüsyon tüpüne alınarak etiketlendi.

Illk denatürasyon $95^{\circ} \mathrm{C} \quad 14,5$ dakika, denatürasyon $97^{\circ} \mathrm{C} \quad 0,5$ dakika, bağlama ve sentez $54^{\circ} \mathrm{C} 1,5$ dakika ve son inkübasyon $22^{\circ} \mathrm{C} 5.0$ dakika olarak 50 döngü tamamlandı. 50 döngünün sonunda $22^{\circ} \mathrm{C}$ 'de 5 dakika bekletilerek, 3 saat sonunda PCR tamamlandı.

\section{Bulgular}

Hemodiyaliz hastalarının \%11,3'ünde (18/160) HBV DNA pozitifliği saptandı ve 18 hasta gizli Hepatit B (GHB) olarak tanımlandı. HBV DNA pozitifliği saptanan hemodiyaliz hasta grubunda HBV DNA düzeyleri 0,6x101-2,973X102 kopya/ml aralığında değişiyordu. Kontrol grubu olan 28 prediyaliz hastasında ise HBV DNA pozitifliğine rastlanmadı.

Tablo 1. Hemodiyaliz ve prediyaliz hastalarının Hepatit belirteçlerinin karşılaştırılması

\begin{tabular}{|c|c|c|c|}
\hline Testler & $\begin{array}{c}\text { Diyaliz Grubu } \\
\text { Pozitiflik \% }\end{array}$ & $\begin{array}{c}\text { Prediyaliz Grubu } \\
\text { Pozitiflik \% }\end{array}$ & P \\
\hline HBV DNA & 11,3 & 0 & 0,080 \\
\hline Anti HBs & 88,7 & 50,0 & 0,001 \\
\hline Anti HBC & 25,6 & 25,0 & 0,999 \\
\hline Anti HCV & 8,1 & 3,6 & 0,698 \\
\hline İzole Anti HBC & 3,1 & 3,6 & 0,999 \\
\hline
\end{tabular}

Anti-HBs pozitifliği hemodiyaliz hastalarının 142 'sinde (\% 88,7), prediyaliz hastalarının ise 14 'ünde (\%50) saptandı. Hemodiyaliz hastalarında AntiHBs pozitifliği prediyaliz hastalarından daha fazlaydı ve istatistiksel olarak anlamlı idi $(\mathrm{P}<0,05)$. Hemodiyaliz ve prediyaliz hastaları arasında Anti$\mathrm{HBC}$, anti-HCV ve İzole anti-HBc pozitiflikleri arasında anlamlı bir fark yoktu $(P>0,05)$.
Tablo 2: Gizli HBV pozitif ve negatif hemodiyaliz hastalarının karşılaştırılması

\begin{tabular}{|c|c|c|c|}
\hline \multirow{2}{*}{ Testler } & $\begin{array}{c}\text { HBV DNA } \\
\text { Pozitif }(\mathbf{n = 1 8})\end{array}$ & $\begin{array}{c}\text { HBV DNA } \\
\text { Negatif }(\mathbf{n}=142)\end{array}$ & P \\
\hline Yaş & $60,17 \pm 15,05$ & $56,97 \pm 16,14$ & 0,424 \\
\hline AST & $12,47 \pm 5,79$ & $13,95 \pm 10,99$ & 0,574 \\
\hline ALT & $11,89 \pm 6,56$ & $13,55 \pm 11,53$ & 0,551 \\
\hline CRP & $24,59 \pm 47,23$ & $14,73 \pm 22,34$ & 0,488 \\
\hline Diyaliz Süresi (Ay) & $79,00 \pm 57,41$ & $59,02 \pm 55,15$ & 0,094 \\
\hline
\end{tabular}

HBV DNA pozitif olan 18 hasta ile HBV DNA negatif 142 hasta karşılaştııldı. Diyaliz sürelerinde gizli Hepatit B saptanan hastalarda belirgin bir yükseklik olmasına rağmen anlamlı bir fark bulunamadı. (P>0,05). Yaş, AST, ALT ve CRP değerleri açısından anlamlı bir fark bulunamadı. ( $P>0,05)$.

Tablo 3: Gizli HBV pozitif ve negatif hemodiyaliz hastalarının Hepatit belirteçlerinin karşılaştırıması

\begin{tabular}{|l|c|c|l|}
\hline Testler & $\begin{array}{l}\text { HBV DNA } \\
\text { Pozitif \% }\end{array}$ & $\begin{array}{l}\text { HBV DNA } \\
\text { Negatif }\end{array}$ & P \\
\hline Anti-HBs & 94,4 & 88,0 & 0,696 \\
\hline Anti-HBC & 22,2 & 26,1 & 0,999 \\
\hline Anti-HCV & 16,7 & 7,0 & 0,166 \\
\hline İzole Anti-HBC & 0,0 & 3,5 & 0,999 \\
\hline
\end{tabular}

Gizli Hepatit B enfeksiyonu ile Hepatit belirteçleri arasında anlamlı bir ilişki bulunamadı ( $P>0,05)$. HCV negatif hastalarda GHB oranı \%10,2 (15/147) iken, HCV pozitif hastalarda GHB oranı \%23,7 (3/13) olarak saptanmıştır.

\section{Tartışma}

Hemodiyaliz uygulanan hastalar potansiyel olarak artan bir HBV ve gizli Hepatit B enfeksiyon riskine sahiptirler. Konağın bozulmuş immün yanıtı, çoklu transfüzyon gereksinimleri, paylaşılan diyaliz ekipmanları, invaziv prosedürler ve HBV aşısının düşük cevabı hemodiyaliz hastalarında gizli Hepatit B bulaşının ana risk faktörlerindendir [10]. Hepatit B aşısı yapılan hemodiyaliz hastalarının yalnızca \%50-60'ında koruyucu antikor cevabı gelişmektedir [11].

Akut Hepatit B geçiren hemodiyaliz hastalarının kronik taşıyıcı olma intimalleri oldukça fazladır. Kronikleşme intimali diyaliz hastası olmayanlar için \%10 iken, bu oran diyaliz hastalarında \%80 seviyesindedir. Ayrıca, HBV taşıyıcısı olan diyaliz hastalarında kronik karaciğer hastalığı gelişme riski de oldukça yüksektir [12].

Hemodiyaliz hastalarında gizli Hepatit B enfeksiyonu prevelans değerlerinde oldukça farkı raporlar vardır. Böbrek diyalizi hastalarında GHB enfeksiyon prevelansı yayınlanan raporlarda \%0-58 arasında değişmektedir [13-16].

Bizim çalışmamızda 160 hemodiyaliz hastasının 18'inde $(\% 11,3)$ gizli Hepatit B enfeksiyonu tespit edildi. Kontrol grubu olan 28 prediyaliz hastasında ise gizli Hepatit $\mathrm{B}$ enfeksiyonuna rastlanmadı.

Gizli Hepatit B'li hastaların serumlarında HBV DNA düzeyi genel olarak 104 kopya/ml'den düşüktür (102-3 kopya/ml serumda, 0,01-0,1 kopya/ 
karaciğer hücresinde) $[17,18]$. Çalışmamızda da gizli Hepatit B olgularının serum HBV DNA düzeyleri oldukça düşük titrelerde olmak üzere 0,6×1012,973×102 kopya/ml aralı̆ı̆nda değişiyordu.

Cabrerizo ve ark. (14)'nın İspanya'da yaptıkları çalısmada hemodiyaliz hastalarında \% 57,6 değeriyle en yüksek GHB oranını buldular.

Motta ve ark. [19] Brezilya'da \%15 (15/100), Minuk ve ark. (20) Kanada'da \%3,8 (9/241), Siagris ve ark. [21] Yunanistan'da \%20,4 (10/49), Di Stefano ve ark. [22] Italya'da \%26,6 (34/128), Aghakhani ve ark. [23] iran'da \%3,11 (9/289), ismail ve ark. [24] Mısı'da \%3,8 (2/116), Mukarem ve ark. [25] yine Misır'da \%4,1 (6/145) ve Albuquerque ve ark. [26] Brezilya'da \%1,5 (3/752) olarak gizli Hepatit B enfeksiyon oranlarını bildirdiler.

Fabrizzi ve ark. [13] italya'da 585 hastada, Tereul ve ark. [27] İspanya'da 61 hastada, Joukar ve ark. [28] İran'da 514 hastada gizli Hepatit B enfeksiyonuna rastlamadılar (GHB oranı \%0).

Türkiye'de de hemodiyaliz hastalarında gizli Hepatit B enfeksiyonu ile ilgili çalışmalar yapıılı ve bildirilen GHB prevelans değerleri oldukça farklılk gösteriyordu. GHB oranları; Altındiş ve ark. [29] \%12,4 (19/153), Sav ve ark. [30] \%16,9 (12/71) olarak bildirdiler.

Türkiye'de yapılan diğer çalışmalarda oranlar daha düşüktü. GHB prevelansları Yakarylmaz ve ark. [31] \%2,7 (5/188), Ersoy ve ark. [32] $\% 1,25(1 / 80)$ ve Goral ve ark. [33] ise $\% 0(0 / 50)$ değerlerini bildirdiler. Doğukan ve ark. [34] HBsAg negatif olan toplam 174 hasta ile yaptıkları çalışmada hemodiyaliz hastalarının \%2,6'sında, periton diyalizi hastalarının \%1,8'inde, prediyalitik hastalarda $\% 0$ olarak bildirdiler.

Hemodiyaliz hastaları arasındaki gizli Hepatit B enfeksiyon prevelansındaki bu farkllıkların nedeni; endemisite, HBV DNA testleri için örnek seçim kriterleri, klinik örnekler ve HBV DNA'nın tespiti için kullanılan metodların farklı sensitivite ve spesifiteye sahip olması ve çalışlan popülasyondaki farkllıklardan dolayı bu tutarsızlıklar ve çelişikili sonuçlar olabilir [7].

Kronik HCV enfeksiyonu olan hastalarda GHB oranları;(Khattab ve ark. [35] \%7,5 (4/53) oranlarında tespit etmişlerdir. Altındiş ve ark.[29]'nın yaptığı çalışmada kronik HCV'li hemodiyaliz hastalarında GHB oranı \% 27,4 (11/40) olarak bildirilmiştir.

Bizim çalışmamızda HCV negatif hastalarda GHB oranı \%10,2 (15/147) iken, HCV pozitif hastalarda GHB oranı \%23,7 (3/13) olarak saptanmıştır. Sonuçlarımız kronik HCV'li hastalarda GHB oranının yüksek olabileceğini desteklemektedir.

Ön çalışmalarda GHB ve aminotransferaz seviyeleri arasında bir ilişki öne sürülmüştür (36). Sav ve ark. [30]'nın araştırmasında; AST ve ALT seviyeleri HBV DNA pozitif hastaların tamamında normal olarak bulunmuş̧ur.

Yakarylımaz ve ark. [31]'nın çalışmalarında AST ve ALT seviyelerinin HBV viremisi olan ve olmayan hastalarda benzer olduğunu gösterdiler.

Fabrizi ve ark. [37]'nın çalsşmalarında serumda AST ve ALT aktiviteleri ile HBsAg / HBV DNA'nın saptanabilirliği arasında anlamlı bir ilişki gösterdiler. AST ve ALT düzeyinin diyaliz hastaları sağlıkı bireylere göre daha düşük olduğunu bildirdiler. Aghakhani ve ark. [7]'nın çalışmalarında gizli Hepatit B enfeksiyonu ile biyokimyasal karaciğer testleri arasında hiçbir ilişki bulunamadl.
Çalışmamızda Gizli HBV enfeksiyonu pozitif olan hastaların AST ve ALT değerleri normal sınırlar içindeydi ve gizli Hepatit B pozitif ve negatif hastalarda AST ve ALT düzeyleri arasında anlamlı fark gözlenmedi $(p>0,05)$. Bu çalş̧malar sonucunda karaciğer fonksiyon testlerinin GHB hastalarııın karaciğer hasarının saptanmasında yararı olabileceğini düşünmemekteyiz.

Diyalize bağımlı olan hastalarda daha belirgin olmakla birlikte kronik böbrek yetersizliği olan hastalarda çeşitli sebeplere bağlı olarak gelişen mikroinflamasyonun belirteci olan CRP değerleri ise gizli Hepatit B pozitif ve negatif hastalar arasında anlamlı bir fark gözlenmedi $(p>0,05)$. Diyaliz sürelerinde gizli Hepatit $B$ saptanan hastalarda belirgin bir yükseklik olmasına rağmen anlamlı bir fark bulunamadı $(p>0,05)$.

Anti-HBs varlığında değişen viral yüklerde HBV DNA pozitiffliği bildirilmiştir. Bu çalışmalarda anti-HBs titresi de değişkenlik göstermekle birlikte pek çok çalışmada >100 IU/ml hatta $1000 \mathrm{IU} / \mathrm{ml}$ ve üstünde anti-HBs düzeyi varlığında bile HBV DNA pozitifliği olduğu gösterilmiştir [38].

Bizim çalışmamızda GHB tanısı alan 18 hastadan 17'sinde anti-HBs pozitifliği vardı ve anti-HBs titreleri oldukça yüksekti.

\section{Sonuç}

GHB enfeksiyonunun tanımlanması için anahtar test HBV DNA 'nın saptanmasıdır. Diyaliz ünitelerinde GHB'li hastaların saptanması gereklidir. Diyaliz uygulanan tüm hastaların HVB DNA taramaları yapılmalıdır. Ayrıca duyarı hastaların aşılanması, GHB tanıı konulmuş hastaların diyalizörlerinin izole edilmesi, HBV tanısı alan hastaların spesifik bir servise alınması önerilebilir.

Bu hastaların ileri takiplerinin yapılarak; viral yüklerinde artış olup olmadığı, karaciğer fonksiyon testlerinde yükselme düzeyi, karaciğer biyopsisinde histolojik değişiklikler araştırıarak gizli Hepatit B enfeksiyonunun tanımlanmasına katkıda bulunacak ve tedaviye yaklaşımın belirlenmesinde yol gösterici olacaktır. Gelecekte yapılacak çalısmalar da gizli Hepatit $B$ enfeksiyonunun klinik önemi ve patogenezinin aydınlatıması ümit edilmektedir.

\section{Kaynaklar}

1. Murray PR, Baron EJ, Jorgensen JH. Manual of Clinical Microbiology. Başustaoğlu A, Kubar A, Yıldıran ŞT ve ark. (çeviren). 9. Baskı, İstanbul: Atlas 2007;8:1721-92.

2. Pawlotsky JM. Hepatitis B virus (HBV) DNA assays (methods and practical use) and viral kinetics. J Hepatol 2003;39:31-5.

3. Al-Moslih Ml, I Sayed AE, Youssef H, and El Majeed AA. Occult Hepatitis $B$ Virus Infection Among Chronic Liver Disease Patients in the United Arab Emirates. International Journal of Infectious Diseases 2008;12:422-30.

4. Beşışık F, Karaca $C$, Akyüz $F$ ve ark. Occult HBV infection and YMDD variants in hemodialysis patients with chronic HCV infection. J Hepatol 2003;38: 506-10.

5. Schreiber GB, Bush MP, Keinman SH, et al The risk of transfusiontransmitted viral infections. N Engl J Med 1996;334:1685-90.

6. Thiers V, Nakajima E, Kremsdorf D, et al Transmission of Hepatitis B from Hepatitis B seronegative subjects. Lancet 1988;2:1273-6. 
7. Aghakhani A, Banifazl M, Velayati AA, et al Occult Hepatitis B virus infection in hemodialysis patients: a concept for consideration. Ther Apher Dial 2012; 16;328-33.

8. Boyacıoğlu S. Hemodiyaliz ve böbrek naklinde Hepatitis B virus enfeksiyonu. Kronik B ve delta hepatiti tanı ve tedavisi 'ulusal uzlaşma toplantısı' III.Ulusal Hepatoloji Kongresi Kitabı 1999;50-8.

9. Hollinger FB, Sood G. Occult Hepatitis B virus infection: a covert operation. J Viral Hepat 2010;17:1-15.

10. Koziel MR, Thio CL. Hepatitis B virus and Hepatitis D virus, Principles and Practice of Infectious Diseases, 7. Edition, Mandell GL, Bennet JE, Dolin R (Ed.). USA, Churchill-Livingstone, 2010;2059-87.

11. Doğukan $A$, Taşkapan $H$, Güven $M$ ve ark. Prediyaliz, hemodiyaliz ve sürekli ayaktan periton diyalizi hastalarında çift doz Hepatit B aşısına yanıt. Türk Nefroloji Diyaliz Hipertansiyon ve Transplantasyon Dergisi 1999;4:192-4.

12. Fabrizi $F$, Martin P. Hepatitis B virus infection in dialysis patients. Am J Nephrol 2000;20:1-11.

13. Fabrizi $F$, Messa PG, Lunghi $G$ et al Occult Hepatitis $B$ virüs infection in dialysis patients: a multicentre survey. Aliment Pharmacol Ther 2005;21: 1341-7.

14. Cabrerizo M, Bartolome J, Caramelo C, et al Molecular analysis of Hepatitis $B$ virus DNA in serum and peripheral blood mononuclear cells from Hepatitis B surface antigen-negative cases. Hepatology 2000;32:116-23.

15. Oesterreicher $\mathrm{C}$, Hammer J, Koch U et al HBV and HCV genome in peripheral blood mononuclear cells in patients undergoing chronic hemodialysis. Kidney Int 1995; 48:1967-71.

16. Minuk GY, Sun DF, Greenberg $R$ et al Occult Hepatitis $B$ virus infection in a North American adult hemodialysis patient population. Hepatology 2004; 40:1072-7.

17. Hu KQ. Occult Hepatitis B Virus Infection and its Clinical Implications. Journal of Viral Hepatitis 2002;9:243-57.

18. Weinberger KM, Bauer T, Bohm S, Jilg W. High genetic variability oh the group specific a determinant of Hepatitis B virus surface antigen and the corresponding fragment of the viral polymerase in chronic virus carriers lacking detectable HBsAg in serum. J General Virol 2000;81:1165-74.

19. Motta JS, Mello FC, Lago BV, et al Occult Hepatitis B virus infection and lamivudine-resistant mutations in isolates from renal patients undergoing hemodialysis. J Gastroenterol Hepatol 2010;25:101-6.

20. Minuk GY, Sun DF, Greenber R, et al Occult Hepatitis B virüs infection in a North American adult hemodialysis patient population. Hepatology 2004; 21:1341-7

21. Siagris $D$, Christofidou $M$, Triga $K$, et al Occult Hepatitis $B$ virüs infection in hemodialysis patient with chronic HCV infection. J Nephrol 2006;19:327-33.

22. Di Stefano M, Stallone G, Tartaglia L, et al Ocult HBV infection in hemodialysis setting is marked by presence of isolated antibodies to HBcAg and HCV. J Nephrol 2009;22:381-6.

23. Aghakhani $A$, Banifazl $M$, Kalantar $E$, et al Occult Hepatitis B virüs infection in hemodiyalysis patient with isolated Hepatitis B core antibady: a multicenter study. Ther Apher Dial 2010;2:113-20.
24. Ismail $H$, Soliman $M$, Ismail N.Occult Hepatitis B virüs infection in Egyption hemodialysis patients with or without hepatitis $C$ virüs infection. Pathol $L a b$ Med Int 2010;16:225-31.

25. Abu El Makarem MA, Abdel Hamid M, Abdel Aleem A, et al Prevalence of occult Hepatitis $B$ virüs infection in hemodialysis patients from Egypt with or without hepatitis C virüs infection. Hepat Mon 2012;12:253-8.

26. Albuquerque ACC, Coelho MRCD, Lemos MF, et al Occult Hepatitis B virüs infection in hemodialysis patients in Recife, Satate of Pernambuco, Brazil. Rev Soc Bras Med Trop 2012;45:558-62.

27. 109. Tereul JL, Mateos LA, Fernandez L, et al Occult Hepatitis B virüs infection in patients treated with chronic hemodialysis. Nefrologia 2005; 23:83-4.

28. Joukar F, Mansour-Ghnael F, Beshraati S, et al Occult Hepatitis B infection in a hemodialysis population in Guilan province, northern Iran. Hemodial Int 2012;16:294-7.

29. Altındiş M, Uslan İ, Çetinkaya Z. ve ark. Hemodiyaliz Hastalarının Gizli Hepatit B Varlığı Yönünden Araştııılması. Mikrobiyoloji Bülteni 2007;41:227-33.

30. Sav T, Gursoy S, Torun E et al Occult HBV infection in continuous ambulatory peritoneal dialysis and hemodialysis patients. Ren Fail 2010;32:74-7.

31. Yakaryilmaz F, Gurbuz OA, Guliter S, Mert A, .Prevalence of occult Hepatitis $B$ and hepatitis $C$ virüs infection in Turkish hemodialysis patients. Ren Fail 2006;28:729-35.

32. Ersoy 0 , Yllmaz R, Arici M ve ark. Prevalence of occult Hepatitis B infection in hemodialysis patients. Dialysis Transplant 2008;362-8.

33. Goral V, Okzul H, Tekes $S$ ve ark. Prevalence of occult HBV infection in hemodialysis patients with chronic HCV. World J Gastroenterol 2006;7:3420-4.

34. Doğukan M, Kizirgil A, Doğukan A. The Investigation of Occult Hepatitis B Infection in Hemodialysis, Peritoneal Dialysis, and Predialysis Patients by the Polymerase Chain Reaction Method. Turkish Nephrology, Dialysis and Transplantation Journal 2009;2:55-61.

35. Khattab E, Chemin I, Vuillermoz I, et al Analysis of HCV co-infection with occult Hepatitis B virus in patients undergoing IFN therapy. J Clin Virol 2005;33:150-7.

36. Habibollahi P, Safari S, Daryani NE, Alavian SM. Occult Hepatitis B infection and its possible impact on chronic hepatitis $\mathrm{C}$ virus infection. Saudi J Gastroenterol 2009;15:220-4.

37. Fabrizi $F$, Mangano S, Alongi $G$ et al Influence of Hepatitis $B$ virus virema upon serum aminotransferase activity in dialysis population. Int J Artif Organs 2003;26:1048-55.

38. Afyon M, Avcı IY, Ülçay A, et al Replication Occult Hepatitis B Virus Infection J Clin Anal Med 2013;4:435-9. 